\title{
BESZÁMOLÓ \\ A VIII. ORSZÁGOS NEVELÉSTUdOMÁNYI KONFERENCIÁRÓL
}

\author{
PERJÉS ISTVÁN* - OLLÉ JÁNOS ${ }^{* *}$ \\ * a Budapesti Corvinus Egyetem Magatartástudományi és Kommunikációelméleti \\ Intézetének egyetemi tanára, intézetigazgatója \\ istvan.perjes@uni-corvinus.hu \\ ** az Eötvös Loránd Tudományegyetem Pedagógiai és Pszichológiai Karának adjunktusa \\ olle.janos@ppk.elte.hu
}

A VIII. Országos Neveléstudományi Konferenciára 2008. november 13-15. között kerül sort - hagyományosan a Magyar Tudományos Akadémia Székházában és a Duna Palotában. Az MTA Pedagógiai Bizottsága a szervezéssel a Budapesti Corvinus Egyetem intézetigazgató egyetemi tanárát, Perjés Istvánt bízta meg. A konferencia titkára Ollé János, az ELTE PPK adjunktusa volt. A Tudományos Szervezőbizottság tagjai Bárdos Jenö, Báthory Zoltán, Hunyady Györgyné, Mátrai Zsuzsanna és Vidákovich Tibor voltak. A konferencia elökészítésében és lebonyolításában további mintegy 50 fö vett részt.

A munka az előző konferencia szakmai és szervezési tapasztalatainak áttekintésével és a konferencianaptár elkészítésével kezdődött, így a szervezők pontos forgatókönyv alapján, az érdeklődők, a résztvevők, valamint a Pedagógiai Bizottság folyamatos tájékoztatásával végezhették munkájukat. Ennek jegyében került sor a szakmai koncepció kidolgozására, a konferencia témaköreinek meghatározására, a szakmai anyagok bírálóinak kiválasztására, a bírálati folyamatra, az előadók, a hazai és külföldi plenáris előadók felkérésére, a szakmai és a kísérő programok kialakítására, az informatikai háttér és a honlap megújítására és müködtetésére, a közremüködő szervezetek, cégek, intézmények munkájának koordinálására, valamint a konferencia lebonyolítására.

A szervezők a konferencia honlapját (www.onk2008.hu), korszerüsítették, s azt számos új szolgáltatással gazdagították (pl. módosították a regisztrációs felületet, a szakmai program helyszínek szerint is kereshetőek voltak, minden előadás és bemutatott poszter tartalmi összefoglalója elérhető, olvasható, névre és tartalomra kereshető, a poszterszekció anyagai a honlapon is elérhetőek, kommentálhatóak, az előadásokat szimpóziumokat interneten közvetítették, igény szerint rögzítették, a szerkesztett előadásokat és szimpóziumokat $\mathrm{CD}$-formátumban elküldik a résztve- 
vőknek. A konferencia eseményeiröl készült fényképek között a honlapon található fényképalbumban tallózhatunk).

A konferencia szakmai koncepcióját az a szándék határozta meg, hogy a hatékony tudomány és a sikeres iskola közötti kapcsolatot egy közössé tett pedagógiai kultúrában is értelmezhessük. Ennek jegyében idei szakmai seregszemlénk a „Hatékony tudomány, pedagógiai kultúra, sikeres iskola" gondolatkörében zajlott le. A konferencia szakmai koncepcióját az alábbiakban foglalta össze a Bizottság: „Válaszút elé érkeztünk. Az elmúlt években a magyar oktatásügy felelős irányítói, kutatói, felsőoktatási és közoktatási szereplői nehéz viták közepette végül a magyar oktatási rendszer európai integrációja mellé álltak. Az ehhez szükséges jogi és gazdasági környezet kialakítása, a bolognai folyamathoz való csatlakozás, a tanárképzés rendszerének átalakítása, a minőségi oktatás validációs biztosítása, a teljesítmény növelése során azonban egyre nyilvánvalóbb, hogy új fejezetet kell nyitnunk a neveléstudomány és a pedagógiai gyakorlat ellentmondásos kapcsolatában is. Mára bizonyossá vált, hogy a gyakran önmagáért való tudomány és az osztálytermekbe zárt erőfeszítések önmagukban nem lesznek képesek az ígért és remélt új pedagógiai kultúra elmélyítéséhez, és egy jobb, élhetőbb, sikeresebb intézményi és személyes életvilág felépítéséhez. Ideje tehát szembenéznünk azzal a dilemmával, miképpen lehet a közös szándékot felelős együttmüködésben is megerősítenünk. A VIII. Országos Neveléstudományi Konferencia azt a célt szolgálja, hogy a hatékony tudomány és a sikeres iskola közötti kapcsolatot egy közössé tett pedagógiai kultúrában is értelmezhessük."

A szervezők arra törekedtek, hogy ez a koncepcionális keret erősen érvényesüljön a három napon, így e gondolatkört vezette be a megnyitó (Perjés István), a nyitó előadás (Arató Gergely: Hatékony tudomány, pedagógiai kultúra, sikeres iskola), a plenáris előadás (Hunyady György: Az érzelmek szociálpszichológiája és a nevelés), s ennek jegyében zártuk a konferenciát is (Barrie Bennett: Systems Changing: A Focus on Instructional Intelligence). A szakmai program megtervezése során a tematikus előadások és a poszterszekciók blokkjaiban is érvényesült ez a koncepció.

A konferencia idén is igen népszerü szakmai programnak bizonyult. A 410 regisztrált résztvevővel lezajlott programsorozatra 11 fő érkezett Kanadából, Horvátországból, Vajdaságból, Szlovéniából, Szlovákiából, Erdélyből és Kárpátaljáról. A szakmai program keretében 75 előadás, 46 poszter és 27 szimpózium (benne további 124 előadás) került sorra. A kísérő rendezvények (Állófogadás az MTA Könyvtártermében, Komolyzenei koncert az MTA Dísztermében, Társas szendvicsvacsora a Duna Palotában) is számos kolléga érdeklődését keltette fel. A konferencia nem számszerüsíthető szellemi szakmai hatásait az élő közvetítés, az előadások rögzítése és a legjobbnak ítélt előadások tanulmánykötetbe válogatása is erősíthette. A konferencia internetes közvetítése révén természetesen ennél jóval többen kísérhették figyelemmel a konferencia eseményeit, határon innen és határon túlról egyaránt. 
A közös kultúraépítés lehetőségét az is erősíthette, hogy bár a szakmai közönség döntő többsége a hazai felsőoktatás mühelyeiből érkezett, de számos oktatáskutató, civil szakmai szervezet, gyakorló pedagógus, egyetemi, föiskolai és doktori iskolai hallgató, könyvkiadó és oktatásinformatikai magáncég is jelen volt a konferencián.

A legsikeresebb előadásokat a Pedagógiai Bizottság tanulmánykötetben kívánja megjelentetni a következő Konferenciára. Az előadók felkérése nyomán a kötet szerkesztési munkája jelenleg is folyik.

A konferencia zárásakor Bárdos Jenő (Pannon Egyetem) vette át a folytonosságot szimbolizáló stafétabotot. 